\title{
RELATION BETWEEN PRE-WARNING TIME AND ACTUAL TRAIN VELOCITY IN AUTOMATIC LEVEL CROSSING SIGNALLING SYSTEMS AT LEVEL CROSSINGS
}

\author{
Jerzy LUKASIK \\ Silesian University of Technology, Faculty of Transport and Aviation Engineering \\ jerzy.lukasik@polsl.pl
}

Abstract

At level crossings equipped with automatic level crossing signalling devices (which are category $\mathrm{B}$ and $\mathrm{C}$ crossings in Poland), warning time depends on several factors including the length of what is referred to as the level crossing's danger zone for road vehicles, and the train velocity. These systems are designed by taking into consideration the maximum train velocity applicable to the given railway line, which is why a train running with a velocity that is lower than the maximum one, e.g. a freight train, produces pre-warning time excess. The pre-warning time excess affects the redundant prolongation of the time when the level crossing is closed for road vehicles. What has been proposed in the article is to reduce the pre-warning time excess by making the pre-warning time depended on the actual train velocity. It describes a structural concept of a solution which should first be implemented in automatic level crossing signalling systems. Owing to adequate assumptions, the concept of the pre-warning time excess reduction exerts no negative effect on safety at level crossings.

Keywords: automatic level crossing signalling systems, pre-warning time, velocity sensor

\section{POWIĄZANIE CZASU OSTRZEGANIA WSTĘPNEGO Z RZECZYWISTĄ PRĘDKOŚCIĄ POCIĄGU W SYSTEMACH SSP NA PRZEJAZDACH KOLEJOWO-DROGOWYCH}

\section{Streszczenie}

Czas ostrzegania na przejazdach kolejowo-drogowych wyposażonych w samoczynną sygnalizację przejazdową SSP (w Polsce przejazdy kategorii B i C), zależy m.in. od długości tzw. strefy niebezpiecznej przejazdu dla pojazdów drogowych oraz prędkości pociągu. Systemy te projektowane są dla prędkości maksymalnej pociągu obowiązującej na danej linii kolejowej, dlatego pociąg jadący z prędkością mniejszą od maksymalnej np. towarowy generuje nadwyżkę czasu ostrzegania wstępnego. Nadwyżka czasu ostrzegania wstępnego wpływa na nadmiarowe wydłużenie czasu zamknięcia przejazdu dla ruchu pojazdów samochodowych. W artykule zaproponowano skrócenie nadwyżki czasu ostrzegania wstępnego przez uzależnienie czasu ostrzegania wstępnego od rzeczywistej prędkości pociągu. Przedstawiono koncepcję struktury rozwiązania, w które należałoby doposażyć systemy samoczynnych sygnalizacji przejazdowych. Dzięki przyjęciu odpowiednich założeń proponowana koncepcja skrócenia nadwyżki czasu ostrzegania wstępnego nie wpływa na obniżenie poziomu bezpieczeństwa na przejazdach kolejowo-drogowych.

Słowa kluczowe: samoczynna sygnalizacja przejazdowa, czas ostrzegania wstępnego, czujnik pomiaru prędkości

\section{INTRODUCTION}

At level crossings equipped with automatic level crossing signalling devices, which are category $\mathrm{B}$ and $\mathrm{C}$ crossings in Poland, the warning time depends on a number of factors, including the length of what is referred to as the crossing's danger zone for road vehicles and the train velocity [24]. Such systems are designed by taking into consideration the train velocity of $\mathrm{V}_{\max }$ applicable to the given railway line, which is why a train running with a velocity that is lower than the maximum one, e.g. a freight train, produces pre-warning time excess. Pre-warning time is the time interval between the moment of automatic activation of traffic lights at the level crossing on account of the train approaching it and the moment when the train front appears at the level crossing. The pre-warning time excess affects the redundant prolongation of the time when the level crossing is closed for road vehicles.

Category B level crossings are those where road traffic is controlled by means of automatic crossing systems featuring traffic lights and level crossing gates closing the road traffic in a direction corresponding to:

- entry to the crossing, or

- entry to the crossing and exit from the crossing.

Category B comprises level crossings of railway lines or sidings and public roads, where:

- the traffic ratio is equal to or higher than 150,000 , or 
- the railway line or siding intersects with a national road.

Category B may also extend over some level crossings of a lower category which do not meet the traffic ratio criterion provided that it is substantiated by the local conditions or the necessity to improve railway or road traffic safety. Category B level crossings can be used where a public road intersects with no more than three tracks at a single crossing, and the railway traffic at the given railway line or siding section does not exceed the maximum velocity of $160 \mathrm{~km} / \mathrm{h}$.

Category $\mathrm{C}$ level crossings are those where road traffic is controlled by means of automatic crossing systems featuring traffic lights only.

Category $\mathrm{C}$ comprises level crossings of railway lines or sidings and public roads where the railway traffic at the given railway line or siding section does not exceed the maximum velocity of 140 $\mathrm{km} / \mathrm{h}$, and:

- the traffic ratio is equal to or higher than 60,000 and lower than 150,000 , or

- the traffic ratio is lower than 60,000, and the level crossing's visibility does not meet the technical requirements applicable to category D level crossings [24].

Level crossings may be equipped with level crossing warning signals which inform the train driver whether or not the devices installed at the level crossing to warn road users are in operation. The level crossing warning signals are installed in a specific distance from the crossing, being not smaller than the braking distance of a train running at the velocity of $\mathrm{V}_{\max }$ applicable at the given railway line. In the event that the level crossing warning signal sends no information that the warning devices have been activated at the crossing, the train driver is obliged to reduce its velocity to such an extent that the train can be stopped before reaching the crossing whenever an obstacle posing a threat to traffic safety is identified at the crossing. Where no such threat is imminent, and yet some incident, e.g. an equipment defect, has occurred, the driver is obliged to continue driving the train with a velocity not higher than $20 \mathrm{~km} / \mathrm{h}$ for as long as it takes for the train front to pass the crossing [9]. As regards the need to maintain the required safety level, the solution proposed in this paper is based on the assumption that level crossings are indeed equipped with level crossing warning signals.

\section{LITERATURE REVIEW}

Level crossings are points of collision between railway traffic and road traffic. The accidents which sometimes happen at these locations involve casualties and significant material losses. Paper [1] specifies the number of incidents and accidents which took place at level crossings in Croatia where $68.4 \%$ of all crossings feature passive protection and only $31.6 \%$ of them are protected by active systems. The problem of safety at level crossings in Poland has been addressed in papers [20, 29, 30]. It should be noted that in Poland, compared to the year 2018, the 2019 accident rate increased for category A level crossings, it remained unaltered for category D, E and F crossings, while it dropped for category B and C crossings. At the same time, the number of category $A$ and $D$ crossings decreased, while the number of category B and C crossings featuring automatic protection systems increased. The author of paper [10] has compared the accident statistics of Finland for both passive and active level crossings by taking direct and fundamental risk factors into consideration. Most accident took place at passively protected crossings. Nearly all direct accident risk factors were attributable to human error. Research has confirmed that active warning devices successfully prevent accidents caused by road traffic participants. The authors of paper [3] have ranked Hungarian level crossings in terms of their safety level with reference to their prioritisation based on a complex scoring system considering accident statistics, traffic volume data and various other traffic engineering aspects. They analysed and modelled a new method in order to calibrate the model. Their results have made it possible to simplify the scoring system used for safety assessment. The authors of paper [21], on the other hand, have emphasised the need for comprehensive monitoring of accidents causes at level crossings and for a computer program to be designed with the level crossing risk monitoring in mind. The authors of paper [17] have attempted to analyse hazardous patterns of behaviour of drivers at level crossings with reference to their on-site observations. Interpretation of the relevant aspects underpinning the drivers' decisions makes it easier to identify the technical solutions which enable the safety level to be increased at level crossings. In paper [19], the researchers have discussed the overall body of problems related the traffic disruptions emerging at level crossings, and not only those attributable to the inappropriate behaviour of traffic participants, but also caused by the proximity of signalcontrolled intersections. The analysis addressed in the paper considered T-type intersections. The publication also provides a solution which assumes that both systems are linked together, and that the signalling control is adequately phased at the nearby intersection. In certain countries, e.g. Canada, the standards applicable to level crossing signals [8] determine the distance between a level crossing and a road intersection at which the signalling systems of both should be interfaced. Paper [32] addresses an analysis conducted by an Expert Group for Safety Improvement at level crossings in the member states of the United Nations Economic Commission for Europe as well as in several other chosen countries. It also describes the strategic framework prepared by the 
Group as the means to increase safety at level crossings. Publication [22] is the Office of Rail and Road strategy for level crossing safety. It covers various aspects, including development of guidelines for risk assessments, research encouragement, innovations, and new technologies. The requirements and standards applicable to level crossings in the UK have been provided in paper [23], documents [9, 24, 25, 33] describe those which apply in Poland, papers [8, 27] concern Canada, and publication [31] addresses the USA. Reference item [28] is a US patent comprising a crossing signal system where the pre-warning time is constant regardless of the train speed. The system consists of the stationary part and suitable equipment installed on board vehicles. Paper [4] addresses results of a study on traffic delays at level crossings in the United Kingdom. The study was intended to determine potential routes allowing for these delays to be reduced, while the paper also provides conclusions concerning different types of crossings in the United Kingdom and how their operations may be associated with the traffic delays. Paper [6] considers the choice between automatic and railway-controlled crossings on public roads in Great Britain. It is found that the valuation of the reduced delays from adopting automatic crossings typically outweighs the valuation of the losses from the increased casualties. However, in practice Britain has chosen to retain a large number of railway-controlled crossings, which implies accepting the delays in return for a good level crossing safety record. The field research in various aspects of safety at railway crossings is the subject of works such as identification of trains and their speed of approaching the crossing and the resulting driver behavior [12], contrasting behaviors of drivers compliant and non-compliant driver behaviour at rural rail level crossings [2], and research on the interactions, errors and escalating risks of users of fully protected level crossings [13]. Apart from this type of research, there are studies devoted to the study of the risk of accidents at level crossings, based on various models. Papers [14, 15] propose risk assessment and making improvement decisions. The studies are aimed at analyzing the various factors that can cause accidents at level crossings, quantifying the contribution of these factors in order to identify the key factors that contribute most to accidents at level crossings. The article [5] presents the application of the modified non-radial DEA model for evaluation of safety at railway level crossings. This model can be used to evaluate the effectiveness of safety improvements at level crossings and the effectiveness of countermeasures before and after implementation. Article [7] discusses the functional control architecture for automatic level crossing signals in the context of ERTMS level 2 and 3. ERTMS 2/3 contains continuous knowledge of train location thanks to connection between the train and the
Radio Block Center. Therefore, the automatic level crossing control scheme should provide optimal level crossing control from the point of view of the train location. Paper [26] presents a study of the vehicle-train collision risk assessment using artificial intelligence, which may lead to the development of a road vehicle-train collision avoidance system on unmanned railroad crossings. Article [18] analyzed the impact of aggressive driving behavior on driver-injury severity at US railroad crossings by considering an extensive set of variables. Following bibliographic items present the problem of abuses and offenses committed by road drivers at rail-road crossings [11, 16]. In [16] the abuses committed by drivers on automatic level crossings equipped with barriers closing the entrance to the crossing in various phases of the closing cycle are discussed. However, in [11] the relationship between waiting time and risky behavior of drivers is discussed. Research has shown that increasing the waiting time results in a higher level of frustration and an increased likelihood of risky behavior, especially for waiting times greater than 3 minutes. The results obtained suggest that the waiting time should be harmonized with values lower than 3 minutes, if possible, to reduce the likelihood of risky behavior by road users. The solution proposed later in the article is a proposal to shorten the excess pre-warning time at rail-road crossings, and thus shorten the waiting time of drivers.

\section{LEVEL CROSSING DANGER ZONE}

The length of the level crossing danger zone has been defined in regulation [24], and it represents a sum of the relevant lengths and distances. Fig. 1 shows the parameters taken into account in the analysis performed by the author with regard to a single track line, where:

$\mathrm{L}_{\mathrm{D}}$ - danger zone length,

$\mathrm{v}=22 \mathrm{~m}-$ length of the set of road vehicles,

$\mathrm{b}=3 \mathrm{~m}$ - road vehicle's braking distance,

$1=1.5 \mathrm{~m}$ - distance between the traffic lights and the crossing gate mechanism assumed with reference to practical applications (according to the applicable requirements, the distance between the traffic lights and the track's outermost rail must not be smaller than $5 \mathrm{~m}$ ),

$\mathrm{g}_{\mathrm{m}}=5 \mathrm{~m}$ - distance between the crossing gate mechanism and the track's outermost rail, $\mathrm{t}=1.435 \mathrm{~m}-$ track gauge.

Assuming the velocity of $2 \mathrm{~m} / \mathrm{s}$ (as per regulation [24]), the time needed by the set of road vehicles to pass through the crossing depicted in Fig. 1 is:

$$
t p_{c a r}=\frac{L_{D}}{V_{c a r}}=\frac{g_{m} \times 2+l+t+b+v}{V_{c a r}}=19[s]
$$

In accordance with regulation [13], the warning time of an automatic level crossing system for the train velocity of $\mathrm{V}_{\max }$ in the given line section should be: 
- at least $8 \mathrm{~s}$ longer than the time needed by a road vehicle running at $2 \mathrm{~m} / \mathrm{s}$ to pass through the danger zone;

- not shorter than $30 \mathrm{~s}$ at category B level crossings equipped with gates preventing entry to the crossing, and at category $\mathrm{C}$ crossings;

- not shorter than $46 \mathrm{~s}$ at category B level crossings equipped with gates preventing entry to and exit from the crossing.

Further elaborations provided in this paper have been conducted for category $\mathrm{B}$ and $\mathrm{C}$ level crossings where the warning times are 46 and 30 seconds4. Determining the possibility for reducing the pre-warning time excess

Fig. 1 depicts the arrangement of the sensors and the required distances between individual elements at the analysed level crossing featuring an automatic level crossing signalling system, but only the sensors considered relevant for the pre-warning time have been taken into account.

The figure contains the following designations: $\mathrm{L}_{b}$ - braking distance,

$\mathrm{L}_{1}$ - distance between the activating sensor and the warning signal,

$\mathrm{L}_{\mathrm{vs}}$ - distance between the velocity sensor and the activating sensor.

The following values of individual parameters were taken into consideration in the author's analyses:

$\mathrm{L}_{\mathrm{b}}$ - braking distance: $1,300 \mathrm{~m}$ for the velocity of $\mathrm{V}_{\max }=160 \mathrm{~km} / \mathrm{h}$, category B level crossing;

$\mathrm{L}_{\mathrm{b}}$ - braking distance: $1,000 \mathrm{~m}$ for the velocity of $\mathrm{V}_{\text {max }}=140 \mathrm{~km} / \mathrm{h}$, category $\mathrm{C}$ level crossing; [33] $\mathrm{w}$ - visibility of signals

$$
w \geq \frac{10 \times V[\mathrm{~km} / \mathrm{h}]}{4}[\mathrm{~m}]
$$

Where $\mathrm{w}<200 \mathrm{~m}$ according to the formula, the minimum value required by the applicable regulations was assumed, i.e. $200 \mathrm{~m}$.

Distance between the activating sensor and the level crossing warning signal:

$$
\begin{gathered}
L_{1}=t_{w}[s] \times V_{\max }[m / s]-L_{b}[m] \geq t_{R}[s] \times \\
V_{\max }[m / s]+w[m]
\end{gathered}
$$

where: $t_{\mathrm{W}}-$ minimum required warning time; $t_{R}$ - system response time; value assumed for $\mathrm{t}_{\mathrm{R}}=2[\mathrm{~s}]$;

When determining the distance of $\mathrm{L}_{1}$, the signal's visibility was assumed as the minimum one required for the velocity of $\mathrm{V}_{\max }$, as applicable to the given railway line (irrespective of the algorithm).

Distance between the velocity sensor and the activating sensor:

$$
L_{v s}=t_{R}[s] \times V_{\max }[\mathrm{m} / \mathrm{s}]
$$

Pre-warning time estimation according to the algorithm which does not take the actual train velocity of $\mathrm{t}_{\mathrm{ws}}$ into account:

$$
t_{w s}=\frac{L_{1}[\mathrm{~m}]-V[\mathrm{~m} / \mathrm{s}] \times t_{r 1}[s]+L_{b}[\mathrm{~m}]}{V[\mathrm{~m} / \mathrm{s}]}[s]
$$

where: $t_{r 1}$ - time interval between the moment when the train runs on the activating sensor and activation of the traffic lights.

Pre-warning time estimation according to the algorithm which takes the actual train velocity of $\mathrm{t}_{\mathrm{wz}}$ into account:

- for the required minimum warning time of $30 \mathrm{~s}$, for category B level crossings equipped with gates preventing entry to the crossing, and for category $\mathrm{C}$ crossings, $\mathrm{t}_{\mathrm{wz} 30}$;

$$
\begin{gathered}
t_{w z 30}=\frac{L_{1}[\mathrm{~m}]-V[\mathrm{~m} / \mathrm{s}] \times t_{r 1}[\mathrm{~s}]+L_{b}[\mathrm{~m}]}{V[\mathrm{~m} / \mathrm{s}]} \\
\frac{L_{1}[\mathrm{~m}]-\left(w[\mathrm{~m}]+V[\mathrm{~m} / \mathrm{s}] \times t_{R}[\mathrm{~s}]\right)}{V[\mathrm{~m} / \mathrm{s}]}[\mathrm{s}]
\end{gathered}
$$

- for the required minimum warning time of $46 \mathrm{~s}$, for category B level crossings equipped with gates preventing entry to and exit from the crossing, twz 46 ;

$$
t_{w z 46}=\frac{L_{b}[\mathrm{~m}]+w[\mathrm{~m}]+V[\mathrm{~m} / \mathrm{s}] \times t_{r 1}[\mathrm{~s}]}{V[\mathrm{~m} / \mathrm{s}]}[\mathrm{s}]
$$

Where time $t_{\mathrm{wz} 46}$ calculated using the formula was shorter than $46 \mathrm{~s}$ (minimum time required by the relevant regulations), then the time of $\mathrm{t}_{\mathrm{wz} 46}=46 \mathrm{~s}$ was assumed.

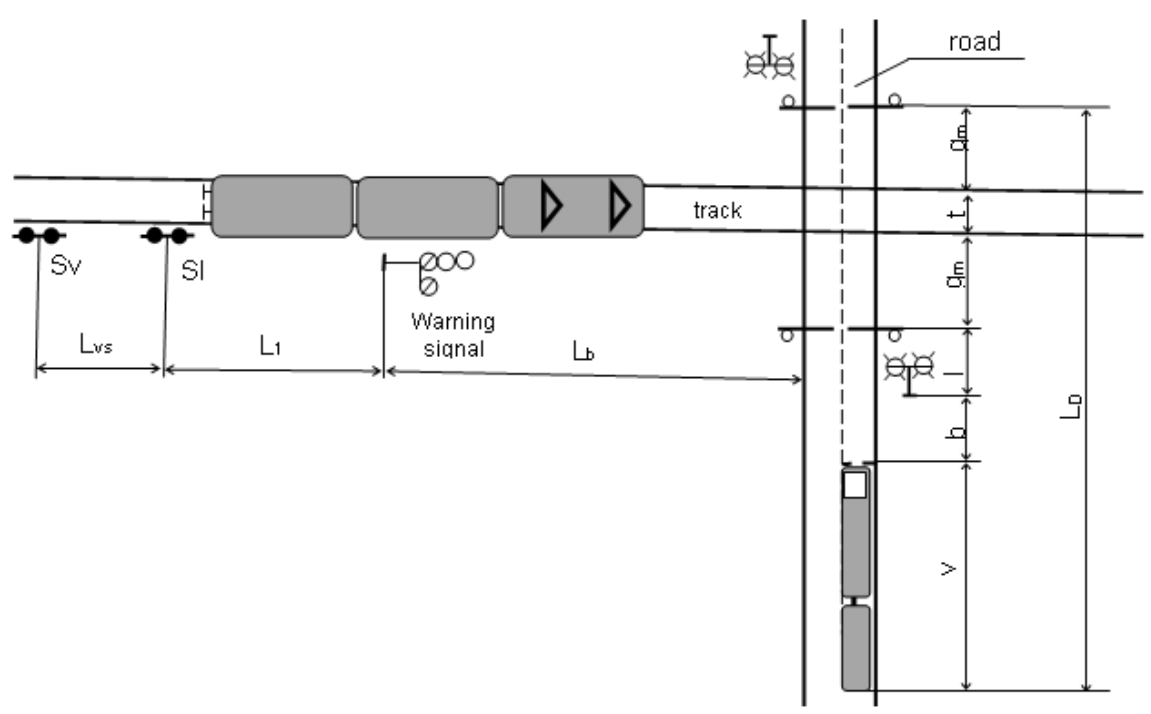

Fig. 1. Level crossing subject to analysis 
The delay in the activation of signalling devices was established as the difference between times $t_{w s}$ and $\mathrm{t}_{\mathrm{wz}}$ subject to the assumption that its value cannot be negative (where this was the case, 0 was assumed).

Sample values of the warning times for trains running with a velocity lower than the maximum one applicable to the given line, for category B and C level crossings, and the potential traffic light activation delay times which could be applied at the crossing have been provided in Table 1 .

Fig. 2 illustrates the pre-warning time for the analysed case of the category B level crossing and the maximum permissible velocity of $160 \mathrm{~km} / \mathrm{h}$ for the railway line, as determined on the basis of the algorithm of fixed warning time $t_{w s}$ and the algorithm of variable warning time $t_{w z}$.
The variable warning time algorithm consists in virtually shifting the traffic light activating sensor towards the crossing for trains running with a velocity lower than the maximum velocity specified for the given railway line, which shortens the time for which the level crossing is inaccessible to vehicular traffic. The solution is based on the required smaller distance corresponding to the visibility of the level crossing warning signal for lower train velocities. The algorithm does not change the physical location of the level crossing warning signal, the distance to which must not be smaller than the required braking distance defined for the velocity of $\mathrm{V}_{\max }$, as applicable to the given railway line. Consequently, having not been informed about the traffic lights being activated

Table 1. Pre-warning times for the level crossings subject to analysis

\begin{tabular}{|c|c|c|c|c|c|c|c|c|c|}
\hline \multirow{4}{*}{ 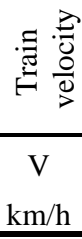 } & \multicolumn{9}{|c|}{ level crossing category } \\
\hline & \multicolumn{6}{|c|}{ category B } & \multirow{2}{*}{\multicolumn{3}{|c|}{$\begin{array}{l}\text { category } \mathbf{C} \\
\min _{\mathrm{w} 30}[\mathrm{~s}]\end{array}$}} \\
\hline & \multicolumn{3}{|c|}{$\min \mathrm{t}_{\mathrm{w} 30}[\mathrm{~s}]$} & \multicolumn{3}{|c|}{$\min \mathrm{t}_{\mathrm{w} 46}[\mathrm{~s}]$} & & & \\
\hline & $\mathrm{t}_{\mathrm{ws} 30}$ & $\mathrm{t}_{\mathrm{wz} 30}$ & delay & $\mathrm{t}_{\mathrm{ws} 46}$ & $\mathrm{t}_{\mathrm{wz} 46}$ & delay & $\mathrm{t}_{\mathrm{ws} 30}$ & $\mathrm{t}_{\mathrm{wz} 30}$ & delay \\
\hline 20 & 321.2 & 271.0 & 50.2 & 375.2 & 271.0 & 104.2 & 256.4 & 217.0 & 39.4 \\
\hline 30 & 213.8 & 181.0 & 32.8 & 249.8 & 181.0 & 68.8 & 170.6 & 145.0 & 25.6 \\
\hline 40 & 160.1 & 136.0 & 24.1 & 187.1 & 136.0 & 51.1 & 127.7 & 109.0 & 18.7 \\
\hline 50 & 127.9 & 109.0 & 18.9 & 149.5 & 109.0 & 40.5 & 102.0 & 87.4 & 14.6 \\
\hline 60 & 106.4 & 91.0 & 15.4 & 124.4 & 91.0 & 33.4 & 84.8 & 73.0 & 11.8 \\
\hline 70 & 91.1 & 78.1 & 12.9 & 106.5 & 78.1 & 28.3 & 72.5 & 62.7 & 9.8 \\
\hline 80 & 79.6 & 68.5 & 11.1 & 93.1 & 68.5 & 24.6 & 63.4 & 55.0 & 8.4 \\
\hline 90 & 70.6 & 62.0 & 8.6 & 82.6 & 62.0 & 20.6 & 56.2 & 50.0 & 6.2 \\
\hline 100 & 63.4 & 56.8 & 6.6 & 74.2 & 56.8 & 17.4 & 50.5 & 46.0 & 4.5 \\
\hline 110 & 57.6 & 52.5 & 5.0 & 67.4 & 52.5 & 14.9 & 45.8 & 42.7 & 3.1 \\
\hline 120 & 52.7 & 49.0 & 3.7 & 61.7 & 49.0 & 12.7 & 41.9 & 40.0 & 1.9 \\
\hline 130 & 48.6 & 46.0 & 2.6 & 56.9 & 46.0 & 10.9 & 38.6 & 37.7 & 0.9 \\
\hline 140 & 45.0 & 43.4 & 1.6 & 52.7 & 46.0 & 6.7 & 35.8 & 35.8 & 0.0 \\
\hline 150 & 42.0 & 41.2 & 0.8 & 49.2 & 46.0 & 3.2 & & & \\
\hline 160 & 39.3 & 39.3 & 0.0 & 46.0 & 46.0 & 0.0 & & & \\
\hline
\end{tabular}

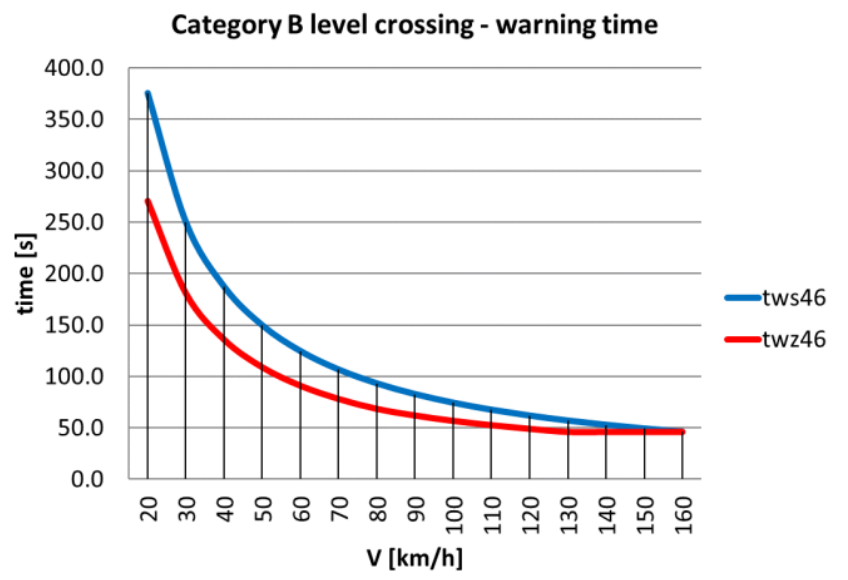

Fig. 2. Pre-warning time for the analysed category B level crossing equipped with gates preventing entry to and exit from the crossing 
at the level crossing, the driver can safely reduce the train velocity when approaching the crossing and follow the regulations applicable in such a case. The study results obtained by the author imply that, with regard to category $\mathrm{B}$ level crossings, using variable pre-warning time, one can shorten the time for which the level crossing is closed for vehicular traffic by as much as ca. $100 \mathrm{~s}$ for a single train compared to the closure time resulting from using fixed warning time. Nevertheless, practical application of this algorithm is only legitimate for the train velocity equal to or lower than $1 / 3$ of the $\mathrm{V}_{\max }$ velocity defined for the given railway line. In the case analysed, the pre-warning time was the consequence of the formal conditions, while in cases where it results, for instance, from the length of the level crossing's danger zone, the values by which the time is shortened may potentially be even higher. In order for the solution in question to be truly effective, the sensor used to measure velocity should be characterised by adequate reliability, while the train should receive information on the need for maintaining constant velocity and not increasing it from the moment when the measurement is taken until reaching the crossing.

\section{STRUCTURE PROPOSED FOR THE SOLUTION}

The solutions used to measure the velocity of a rail vehicle currently available in the market are typically wheel sensors which, when paired with an adequate card, enable successful velocity measurement. The devices used in such solutions are two system sensors which have already proved efficient, for instance in track occupancy control systems where axle counters are successfully used in railways. The railway occupancy control system must be characterised by a high safety integrity level (SIL-4) and high reliability. Consequently, a wheel sensor used as a component of such systems should also be fail-safe. Therefore, using such a sensor in a stationary rail vehicle velocity measurement system seems legitimate. The available solutions comprising a wheel sensor combined with an adequate card enable rail vehicle velocity measurement with an accuracy of $\pm 3 \%$ up to the velocity of $160 \mathrm{~km} / \mathrm{h}$, which is sufficient considering the proposed application in automatic level crossing systems, which may be used where the train velocity does not exceed $160 \mathrm{~km} / \mathrm{h}$. The card paired with the sensor receives information about the measured velocity in a binary format. Fig. 3 depicts the structure proposed for the solution in question. The terminal card operating on the basis of the signals received from the velocity sensor develops information about the measured velocity in the binary format, which is then transferred to the automatic level crossing signalling systems via an adequate interface.

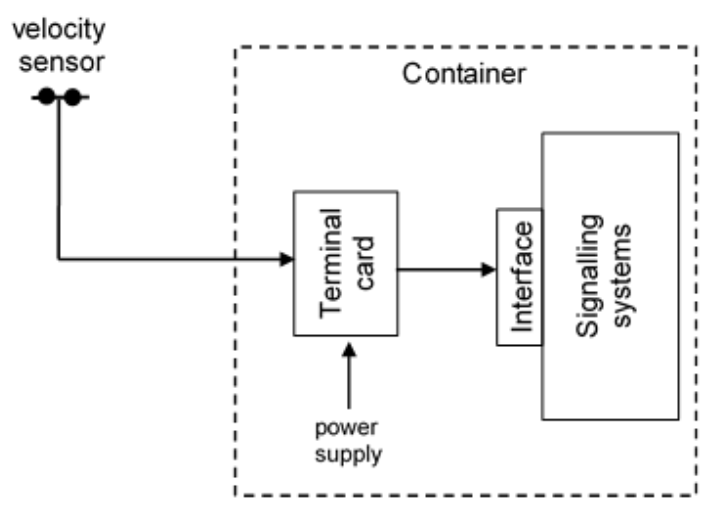

Fig. 3. Connection between the velocity sensor and the signalling systems

It is assumed that the automatic level crossing signalling system's function will consist in activating the warning signals at the level crossing with a variable pre-warning time based on the data received from the sensor's terminal card. Besides the velocity measurements, the terminal card can also provide the status of and the diagnostic information about itself as well as the sensor. Using this information makes it possible to reduce the negative impact of the fallibility of the components such as the velocity sensor and the terminal card on the reliability of the automatic level crossing signalling system. In the event that, for instance, the card provides a wrong status or information on a defect of the card itself or of the velocity sensor, the automatic level crossing signalling system could deactivate the variable time feature and enable the crossing warning functions without the delay related to the actual train velocity. Such an approach makes it possible to sustain the fundamental functionality of the automatic level crossing signalling system regardless of the new elements introduced, such as the velocity sensor or the terminal card.

The solution proposed by the author does not require any specialised equipment to be installed on board rail vehicles, and it will prove cheaper than the solution applied in the USA. The American system [28] ensures warning at level crossings with fixed time, regardless of the train speed, and it comprises both stationary and on-board devices. While approaching a level crossing, a rail vehicle integrated with this system provides stationary devices with information about the time in which it will reach the crossing, and sends this information several times, and on such a basis, it is established when the crossing warning signals are to be enabled. Moreover, the procedure of submitting information several times makes it possible to verify the train speed and to check if it has not changed. What this system also requires is equipment enabling the train route to be programmed. The solution proposed by the author will be more cost-effective. Although it does not provide continuous train speed monitoring, yet in the event that the train should accelerate after 
passing a speed control sensor, this concept ensures that the driver approaching a level crossing warning signal can notice its warning that the crossing is not protected. This obligates the driver to reduce the speed to a level which enables the train to be stopped before reaching the level crossing in the event that there are any obstacles at the crossing. Otherwise, if there are no such obstacles, the train can safely enter the crossing at a speed of $20 \mathrm{~km} / \mathrm{h}$. This is possible because, according to the solution proposed, the distance at which level crossing warning signals are set from the crossing itself is not smaller than the required braking distance for the speed of Vmax, as defined for the given railway line. Even though this solution does not ensure fixed warning time in all cases, irrespective of the train's actual running speed, it is effective from the perspective of safety assurance, making it possible to reduce the pre-warning time excess at level crossings, thus shortening the time for which the crossing is closed for road vehicles.

\section{CONCLUSIONS}

Using the variable pre-warning time feature at level crossings equipped with automatic signalling systems, the time for which the crossing is unavailable to road traffic can be reduced, while at the same time the required minimum warning times are maintained. Application of the algorithm in question is substantiated for trains running with the velocity equal to or lower than $1 / 3$ of the $\mathrm{V}_{\max }$ velocity defined for the given railway line.

In order for this solution to be effective, the sensor used to measure velocity should be characterised by adequate reliability, while the train should receive information on the need for maintaining constant velocity and not increasing it from the moment when the measurement is taken until reaching the crossing. The solution proposed by the author has no impact on the physical location of the level crossing warning signals, the distance to which must not be smaller than the required braking distance defined for the velocity of $\mathrm{V}_{\max }$, as applicable to the given railway line, which is why no defect of the velocity sensor or driver's failure to maintain constant velocity should pose any threat to traffic safety. Moreover, this solution enables the system to disable the variable pre-warning time option and apply fixed warning time defined for the train velocity of $\mathrm{V}_{\max }$ whenever any defect or abnormality is found in the operation of the velocity sensor or its terminal card.

\section{REFERENCES}

1. Badanjak D, Barić D, Novačko L. Current safety situation at level crossings in Croatia and the future research. WIT Transactions on the Built Environment. 108:595-604. https://doi.org/10.2495/SAFE090551.
2. Beanland V, Salmon P. M, Filtness A. J, Lenné M. G, Stanton N. A. To stop or not to stop: Contrasting compliant and non-compliant driver behaviour at rural rail level crossings. Accident Analysis and Prevention. 2017;108:209-219.

https://doi.org/10.1016/j.aap.2017.09.004.

3. Borsos A, Gabor M, Koren C. Safety ranking of railway crossings in Hungary. Transportation Research Procedia. 2016;14:2111-2120. https://doi.org/10.1016/j.trpro.2016.05.226.

4. Delmonte E, Tong S.: Investigation into traffic delays at level crossings. Published Project Report PPR377, TRL. 2008.

5. Djordjević B, Krmac E, Mlinarić TJ. Non-radial DEA model: A new approach to evaluation of safety at railway level crossings. Safety Science. 2018; 103:234-246.

https://doi.org/10.1016/j.ssci.2017.12.001.

6. Evans AW, Hughes P. Traverses, delays and fatalities at railway level crossings in Great Britain. level crossings. Accident Analysis and Prevention. 2019;129:66-75. https://doi.org/10.1016/j.aap.2019.05.006.

7. Ghazel MA Control scheme for automatic level crossings under the ERTMS/ETCS Level 2/3 Operation. IEEE Transactions on Intelligent Transportation Systems. 2017; 18(10): 2667-2680.

8. Government of Canada, Transport Canada. Grade Crossings Standards. 2019, https://tc.canada.ca/en/railtransportation/standards/grade-crossings-standards [19.02.2021].

9. Instrukcja sygnalizacji Ie-1 (E-1). Instrukcja PKP PLK S.A. 2019. Polish.

10. Laapotti S. Comparison of fatal motor vehicle accidents at passive and active railway level crossings in Finland. IATSS Research. 2016;40:1-6. https://doi.org/10.1016/j.iatssr.2015.12.003.

11. Larue GS, Blackman RA, Freeman J. Frustration at congested railway level crossings: How long before extended closures result in risky behaviours? Applied Ergonomics. 2020; 82:102943. https://doi.org/10.1016/j.apergo.2019.102943.

12. Larue GS, Filtness AJ, Wood JM, Demmel S, Watling CN, Naweed A, Rakotonirainy A. Is it safe to cross? Identification of trains and their approach speed at level crossings. Safety Science. 2018; 103: 33-42. https://doi.org/10.1016/j.ssci.2017.11.009.

13. Larue GS, Naweed A, Rodwell D. The road user, the pedestrian, and me: Investigating the interactions, errors and escalating risks of users of fully protected level crossings. Safety Science. 2018; 110:80-88. https://doi.org/10.1016/j.ssci.2018.02.007.

14. Liang C, Ghazel M. A risk assessment study on accidents at French level crossings using Bayesian belief networks. International Journal of Injury Control and Safety Promotion. 2018; 25(2): 162-172. https://doi.org/10.1080/17457300.2017.1416480.

15. Liang C, Ghazel M, Cazier O, Bouillaut L. Advanced model-based risk reasoning on automatic railway level crossings. Safety Science. 2020; 124 (104592). https://doi.org/10.1016/j.ssci.2019.104592.

16. Liang C, Ghazel M, Cazier O, El Koursi EM. A new insight on the risky behavior of motorists at railway level crossings: An observational field study. Accident Analysis and Prevention. 2017; 108: 181188. https://doi.org/10.1016/j.aap.2017.08.030. 
17. Liang C, Ghazel M, Cazier O, El Koursi EM. Analyzing risky behavior of motorists during the closure cycle of railway level crossings. Safety science. 2018;110:115-126. https://doi.org/10.1016/j.ssci.2017.12.008.

18. Ma C, Hao W, Xiang W, Yan W. The Impact of Aggressive Driving Behavior on Driver-Injury Severity at Highway-Rail Grade Crossings Accidents. Journal of Advanced Transportation. 2018: 9841498. https://doi.org/10.1155/2018/9841498.

19. Michalík R, Janota A, Nemec D, Hruboš M. Cooperation of the control logic of the T-shape road intersection and the near railway level crossing. Transportation Research Procedia. 2019; 40: 14651472. https://doi.org/10.1016/j.trpro.2019.07.203.

20. Najwyższa Izba Kontroli, Departament Infrastruktury. Bezpieczeństwo ruchu na przejściach i przejazdach kolejowo-drogowych, Informacja o wynikach kontroli. Nr ewid. 200/2016/P/16/029/KIN. Warszawa. 2017.

21. Nedeliaková E, Sekulová J, Nedeliak I. A New Approach to the Identification of Rail Risk at Level Crossing. Procedia Engineering. 2016; 134: 40-47. https://doi.org/10.1016/j.proeng.2016.01.036.

22. Office of Rail and Road. Strategy for regulation of health and safety risks -4 : level crossings. February 2020.

23. Office of Rail Regulation: Level crossings: A guide for managers, designers and operators, Railway Safety Publication. 2011,

https://orr.gov.uk/ data/assets/pdf file/0016/2158/le vel_crossings_guidance.pdf [18.03.2020 r.]

24. Rozporządzenie Ministra Infrastruktury i Rozwoju w sprawie warunków technicznych, jakim powinny odpowiadać skrzyżowania linii kolejowych oraz bocznic kolejowych z drogami i ich usytuowanie. Dz. U. z 2015 r. poz. 1744. Polish.

25. Rozporządzenie Ministra Infrastruktury zmieniające rozporządzenie w sprawie warunków technicznych, jakim powinny odpowiadać skrzyżowania linii kolejowych oraz bocznic kolejowych z drogami i ich usytuowanie. Dz. U. z 2018 r. poz. 1876. Polish.

26. Singhal V, Jain S., Anand D, Singh A, Verma S, Kavita, Rodrigues JJ, Jhanjhi NZ, Ghosh U, Jo O, Iwendi C. Artificial intelligence enabled road vehicletrain collision risk assessment framework for unmanned railway level crossings. IEEE Access. 2020,8:113790-113806. https://doi.org/10.1109/ACCESS.2020.3002416.

27. Transport Canada, Rail Safety Branch. Grade Crossing - Handbook,

https://tc.canada.ca/en/rail-transportation/gradecrossings/grade-crossings-handbook [19.02.2021].

28. United States Patent, US009 126609B2. Systems and methods for controlling warnings at vehicle crossings.https://patentimages.storage.googleapis.co $\mathrm{m} / 52 / \mathrm{e} 8 / \mathrm{ab} / \mathrm{cc} 80701 \mathrm{~d} 0 \mathrm{fe} 93 \mathrm{f} / \mathrm{US} 9150229 . \mathrm{pdf}$ [21.02.2021]

29. Urząd Transportu Kolejowego. Sprawozdanie ze stanu bezpieczeństwa ruchu kolejowego w 2018 r., Warszawa 2019. Polish.

30. Urząd Transportu Kolejowego. Sprawozdanie ze stanu bezpieczeństwa ruchu kolejowego w 2019 r., Warszawa 2020. Polish.

31. U.S. Department of Transportation, Federal Highway Administration. Highway-Rail Crossing Handbook Third Edition. https://safety.fhwa.dot.gov/hsip/xings/com_roaduser/f hwasa18040/chp2f.cfm [21.02.2021].

32. Working Party on Rail Transport, Assessment of safety at level crossings in UNECE member countries and other selected countries and strategic framework for improving safety at level crossings. Informal document SC. 2016; 2(5)

https://www.unece.org/fileadmin/DAM/trans/doc/201 6/sc2/ECE-TRANS-SC2-2016-id05e.pdf [20.03.2020].

33. Wytyczne techniczne budowy urządzeń sterowania ruchem kolejowym Ie-4 (WTB-E10). Instrukcja PKP PLK S.A. 2019 r. Polish.

Received 2020-10-27

Accepted 2021-02-25

Available online 2021-03-02

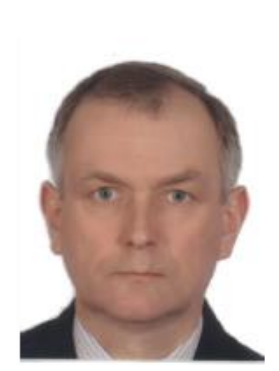

Jerzy LUKASIK MSc Assistant at the Department of Rail Transport at the Faculty of Transport and Aviation Engineering of the Silesian University of Technology. The research area is railway automation, systems and devices of railway traffic control. Currently I am dealing with the problems of rail-road crossings. 